\title{
MALIGNANT OTITIS EXTERNA - VARIABILITY OF CLINICAL COURSE AND DIFFICULTIES OF DIAGNOSTICS
}

KORESPONDENT

\section{AUTHORS}

Janićijević $M$.

Faculty of Medicine, Pristina - Department of Otorhinolaryngology

\section{MILOŠ JANIĆIJEVIĆ}

Faculty of Medicine, Pristina Department of Otorhinolaryngology

$\triangle$ milosjanicijevic@yahoo.com

\section{SUMMARY}

This paper shows the case of a 70-year-old diabetic patient who was admitted to the ORL and MFS clinic as an emergency case with the right ear otalgia, in the right mastoid extension, facialis paralysis and the right ear suppuration all of which lasted for a month before the hospitalization. On admission, the innitial diagnostics stated canal skin edema of the external hearing canal which made the eardrum impossible to visualize. Granulations at the bottom of the canal were visible. During the admission, the patient was submitted to conservative and surgical treatments which confirmed that it was the case of malignant otitis externa.

Keywords: facialis paralysis, suppuration, otalgia, granulations, diabetes mellitus

\section{INTRODUCTION}

Malignant otitis externa (MOE) is a necrotizing infection of external hearing canal (ehc) with propagation toward deeper soft structures or bone structures where it can cause osteomyelitis of temporal bone in immunocompromised patients and patients with severe cronic diseases. Chendler published the first series of patients with progressive osteomyelitis of temporal bone and named it malignant otitis externa [1]. In 1982. Doroghazi and assoc. gave the first systematic review of symptoms and signs characteristic for this disease (persistant otorrhea, strong headache, facialis paralysis, partial deafness, trismus, the presence of granulations at the bottom of the canal). Prior to era of antibiotics MOE was the disease with about $50 \%$ of mortality [1]. Epidemiological diabetes mellitus is one of the main affiliated factors important for the development of this disease. According to the study of Matthew and assoc. from 2007, 65\% of patients out of 46 cases of MOE had diabetes mellitus [9]. Microbiologically, the most frequent cause of $\mathrm{MOE}$ is Pseudomonas aeruginosa in $95 \%$ of cases. Other causes are: Staphylococcus aureus [3], Staphylococcus Epidermidis [4], Proteus mirabilis [5], Klebsiella oxytoca [6], Aspergillus fumigatus, A. niger, Candida parapsilosis. According to Hobson and associates' study from 2014, there are two types of MOE: type 1 - caused by Pseudomonas and type 2 - caused by other microorganisms [2].

The aim of this paper is to indicate the difficultis of diagnosing this disease precisely because of its malignant course, different causes, variable clinical course and distinct tendency to different severe complications.

\section{CASE REPORT}

A 70-year-old patient was admissioned to the ORL and MFS clinic as an emergency case of facialis paralysis of the right side followed by pain and right ear suppuration. The simptoms began a month before the admission. The patient was treated with the conservative therapy that showed no improvement. He's had diabetes mellitus for 20 years on insulin therapy. By clinical ORL exam and otomicroskopy on admission the skin edema of ehc and granulations at the bottom of the right canal were stated. The access itno the eardrum was impossible because of extremely expressed edema of ehc. The mastoid area was palpatory painfully sensitive with tumefaction behind the mandibula angle which was vaguely borded. The facialis paralysis on the right side is of peripheral type. Sensorineural hearing loss on both sides up to $80 \mathrm{db}$ of high frequency was stated with tone audiometry. The right ear swab was taken and it showed the presence of Candida spp. The laboratory mediators of inflammation were within the limit of reference range. Glucose was 7.5; Urea 1.0; Creatinine 106. MRI of endocranium was also done: in mastoid cells and the external hearing canal on the right side there was a pathological content of heterogeneous presence with no post contrast enhancement. Ehc on the right side is very narrow, to the crack diameter. The lesion is in contact with the front and lateral wall of sigmoid sinus with no signs of its infiltration, it comprimes ehc lummen and makes it narrow (Pictires 1, 2).

The patient was also submitted to MDCT of temporal bone that showed pathological content in the right mastoid but the structures in the middle ear were conserved (pictures 3, 4). According to all the test results as well as the clinical picture that showed regular 
otitis externa, facialis paralysis, mastoiditis and malignant otitis externa it was decided that the patient should be submitted to surgical treatment with goal of removing pathological process from the right ehc, mastoid and cavum.

Picture 1. MRI of endocranium - pathological content in the right mastoid is visible as well as the very narrow right ehc lumen

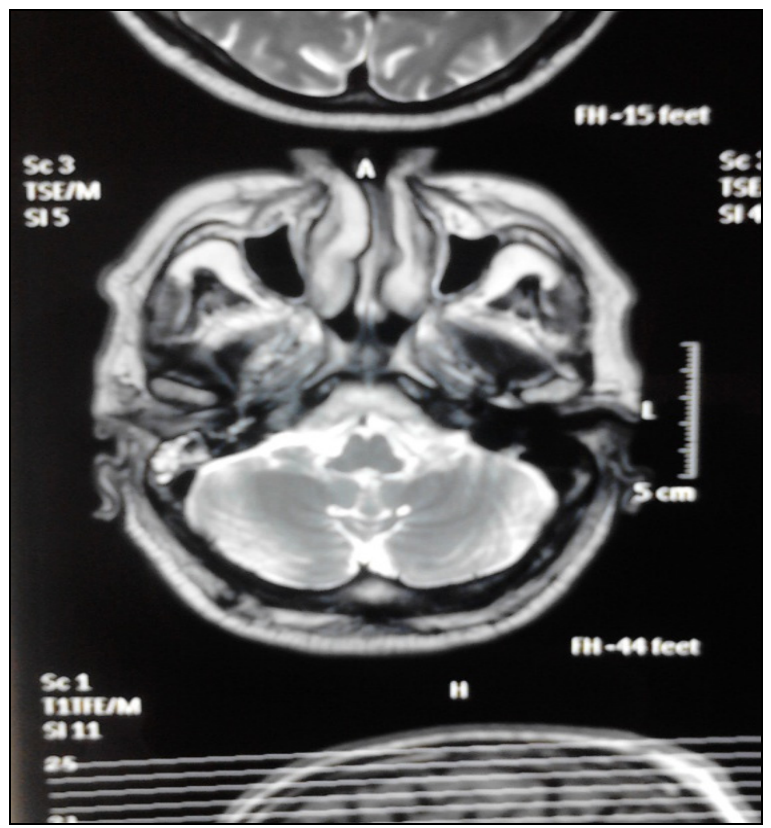

Picture 2. MRI of endocranium-shows the progres in the right mastoid extension

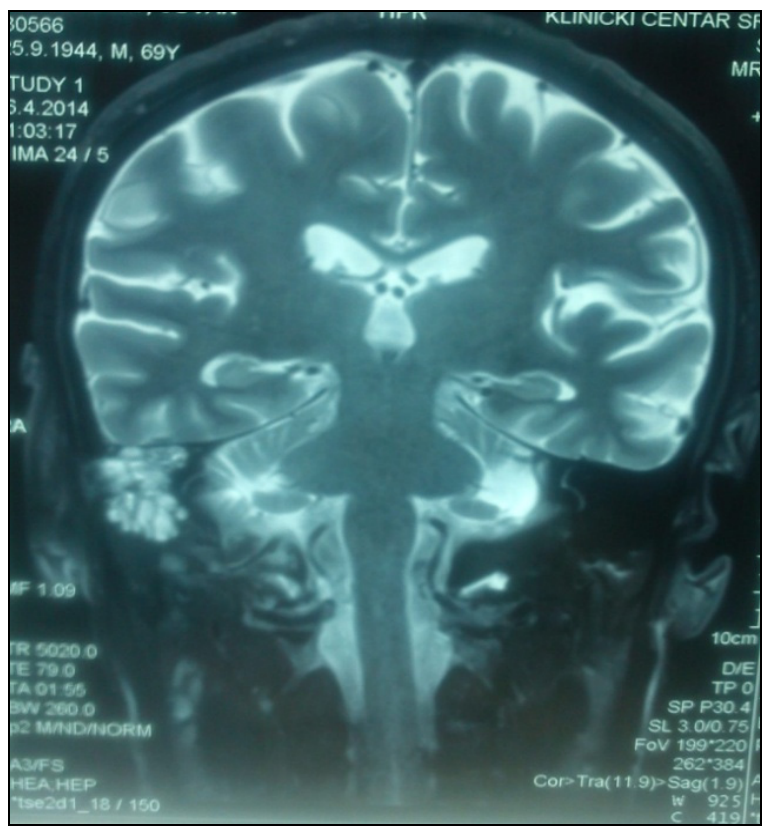

The patients were submitted to: Excisio cutis MAE lat. dex, Aticotomia posterior lat. dex et Mastoidectomia lat. dex. The intraoperative test result showed that the skin of ehc was extremely hypertrophic, fattened and of granulomatous complexion. Two preparations of excidium skin of ehc were sent to $\mathrm{PH}$ analysis (they both showd the case of perivascular, acutely chronic inflammation). The last atticotomy and mastoidectomy were done and they showed that the mastoid bone was pneumatized, antrum was developed, no granulation was formed, but the bone berriers showed signs of inflammation. Part of mucosal barrier of the bone was sent to the $\mathrm{PH}$ analysis ( $\mathrm{PH}$ analysis showed multiple fragments of little cellular connective tissue with signs of simple chronic inflammation and fragments of partially necrotic calcificated bone).

Pictures 3 and 4: MSCT of temporal bones - shows reduced pneumatization of the right mastoid with the preserved structures in cavum
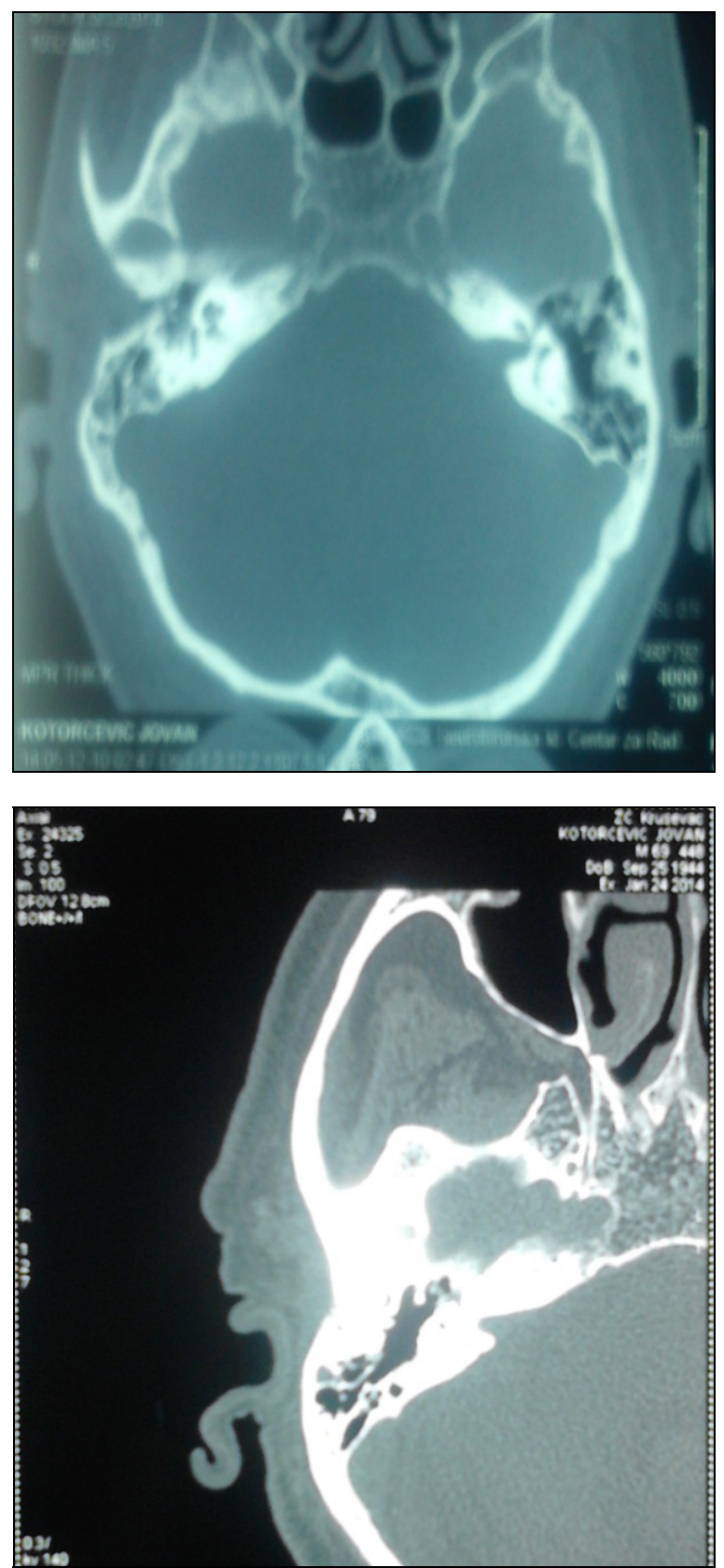

During the admittion the patient was treated with the conservative therapy as well that lasted for 2 weeks (with Lincosamides and Cephalosporins). It was pathologically confirmed that the ehc infection caused mastoiditis and facialis paralysis and therefore disguised the initial disease. Owing to the clinical and otoscopic 
test results improvement the patient was released from clinic with the recommendation to start a physical treatment in the center for facial nerve rehabilitation. At the check-up, the results were much better.

\section{DISCUSION}

Ever since their first publications (Meltzer and Kelman 1959.) it was clear that MOE was a disease with quite variable clinical course that gives a different clinical picture so it is difficult to suspect it at the beginning. In 1986. Clinton and assoc. described a case of a patient with retrobulbar neuritis who had been treated for malignant otitis for over a year. Most of the authors assert that at the beginning this disease is hard to differentiate from otitis extrerna. However, if there is resistency to the applied therapy the propagation of infection on the surrounding structures is enough to throw suspicion on MOE. Abscesses or granulations at the bottom of ehc are pathognomonic sign of this disease. CT and MRI should facilitate in great degree the diagnostics, that was the case here, first of all because of the findings in mastoid and extremely diminished lummen of ehc. Technetium 99 scan is a method that diagnoses MOE $100 \%$. Technetium 99 is radioisotop with the affinity to precipitate in the areas with intensive osteoclast and osteblastic activity, places with infection, trauma and neoplasm [11]. Scanning with gallium 67 is also used. It precipitates in macrophages, reticuloendotelial system cells, granulocytes and bacteria [12]. There are no standardized imaging criteria that could with certainty confirm that it's the case of MOE. One of characteristic signs is presence of erosions on bones that are attaced by the process, but the precaution is needed at the estimation because of the differential diagnosis compared to malignity $[7,8]$.

Microbiological result is of great significance in diagnosing MOE. As already stated, in about $95 \%$ of cases what causes it is Pseudomonas aeruginosa. Microbiological result is also important because of the possibility of MOE caused by different strains as well as the great deal of resistency. In the study from 2014. (Hobson and assoc.), it was proved that MOE caused by methicillin resistant Staphylococcus aureus was treated approximately 2.4 weeks longer than MOE caused by Pseudomonas aeruginos [2]. Bergholz and assoc. in their study proved that $33 \%$ of MOE caused by Pseudomonas bacretia showed high resistency on Ciprofloxacin [10].

Table 1. The role of Tc99, Ga67 and CT in diagnosing MOE and malignity

\begin{tabular}{lccc}
\hline \multicolumn{1}{c}{ Disease } & Ga67 & Tc99 & CT \\
\hline Otitis externa & + & - & - \\
\hline MOE & + & + & $(+)-)^{-}$ \\
\hline Skull base osteomyelitis & + & + & + \\
Recurrent MOE & $\begin{array}{c}(-) \text { After Th } \\
\text { Then }(+)\end{array}$ & + \\
\hline Malignity & - & + & + \\
\hline
\end{tabular}

Standard laboratory tests include sedimentation rate of erythrocytes, CRP, leukocyte formula, fibrinogen, hematocrit and glucose but all unspecified so these tests have to match the complete diagnostic picture in order for MOE to be adequately diagnosed and treated [9].

Paresis and paralysis of cranial nerves are usually indicators of the advanced disease so diagnosing at this stage does not help much with prevention of appearing of permanent sequels and severe deformities and possibly lethal outcome. Cranial nerve defects appear in $40 \%$ of patients, mostly paralysis of facial nerve. Facialis paralysis is exactly what gives the bad prognosis of the disease as well as the longer recovery period. The bad prognosis factor includes infection with Aspergillus, MRI result of affection in the middle cranial fossa or foramen magnum [14].

\section{CONCLUSION}

This case was presented because it is very interesting and its pathology is rare. The clinical picture resembled to some other disease for a long time and only the complete diagnosics and surgical therapy confirmed that it was the case of MOE with complications in mastoid and facial nerve lesia. The great problem is the fact that there are yet no standard diagnostic criteria for MOE, but they vary from one author to another. What we

Table 2. Diagnostical criteria of MOE according to the data from bibliography

\begin{tabular}{|c|c|c|c|c|c|c|c|c|c|c|c|c|c|c|c|c|c|c|c|}
\hline ঠ్ & 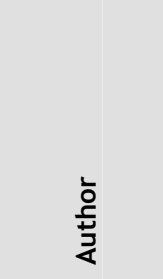 & 氉 & 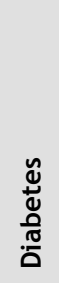 & 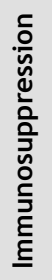 & 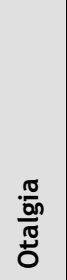 & 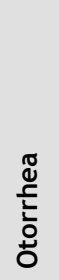 & 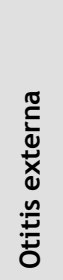 & 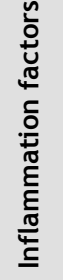 & 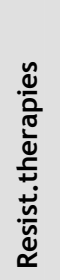 & 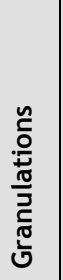 & 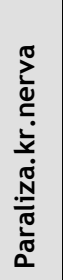 & 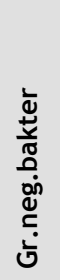 & 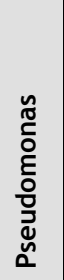 & 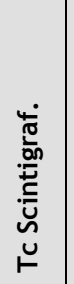 & 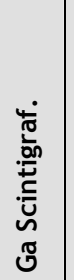 & Ł̌ & 岕 & 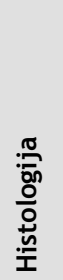 & 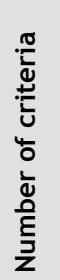 \\
\hline 1989 & Sade & & & & & & & & & & & & & & & & & & 4 \\
\hline $1990^{\circ}$ & Levy & & & & & & & & & & & & & & & & & & 4 \\
\hline 2002 & Berenho & & & & & & & & & & & & & & & & & & 3 \\
\hline 2003 & Karantanas & & & & & & & & & & & & & & & & & & 4 \\
\hline 2007 & Mani & & & & & & & & & & & & & & & & & & 3 \\
\hline 2008 & Joshua & & & & & & & & & & & & & & & & & & \\
\hline 2008 & Sudhoff & & & & & & & & & & & & & & & & & & 3 \\
\hline $2010^{\circ}$ & & & & & & & & & & & & & & & & & & & 4 \\
\hline & Čhen & & & & & & & & & & & & & & & & & & \\
\hline
\end{tabular}


should be especially focused on in the future is the control of affiliated factors like diabetes mellitus and different conditions that cause immunodeficiency.

\section{REFERENCES}

1. Chandler JR. Malignant otitis externa, Laryngoscope 1968;78:1257-92

2. Hobson CE, Moy JD, Byers KE, Raz Y, Hirsch BE, McCall AA.Malignant otitis externa:Evolving Pathogens and implications for Diagnosis andtreatment.Otolaryngol Head NeckSurg.2014 Mar 26

3. Bayardelle P, Jolivet-Granger M, Larochelle D. Staphylococcal malignant external otitis. Can Med Assoc J 1982;126:155-6

4. Barow HN, Levenson MJ. Necrotizing malignant external otitis caused by Staphylococcus epidermidis. Arch Otolaryngol Head Neck Surg 1992;118:94-6

5. Coser PL, Stamm AE, Labo RC et al. Malignant external otitis in infants. Laryngoscope 1980; 90:312-6

6. Garcia Rodriguez JA, Mantes Martinez I, Gomez Gonzalez JL, et al. A case of malignant external otitis involving Klebsiella oxytoca. Eur J Clin Microbiol infect Dis 1992;11:75-7

7. Mayers BR, Mendelson MH, Parisier SC, et al. Malignant external otitis comparison of monoterapy vs combination terapy. Arch Otolaryngol Head Neck Surg 1987;113:974-8

8. Grandis JR, Curtin HD, Yu VL. Necrotizing(malignant) external otitis:prospective comparison of CT and MR imaging in diagnosis and follow-up. Radiology 1995;196:499-504

9. Franco-Vidal V, Blanchet H, Bebear C,et al. Necrotiying external otitis: a repeat of 46 cases. Otol Neurootol 2007;28:771-3

10. Berholz L, Katzenell U, Harell M. Evolving resistant pseudomonas to ciprofloxacin in malignant external otitis. Laryngoscope 2002;112:1616-22

11. Strashun AM, Nejatheim M, Goldsmith SJ. Malignant external otitis:oerly scintigraphic detection. Radiology 1984;150:541-5

12. Stokkel MP, Boot CN, Von Eck-Smit BL. SPECT gallium scintigraphy in malignant external otitis: initial staging and follow-up. Case reports. Laryngoscope 1996;106:338-40

13. Mathew J.Carfrae, Bradley W.Kesser. Malignant Otitis externa. Otolaryngol Clin N Am 2008;41: 541-42

14. Kwon BJ, Han $\mathrm{MH}$, Oh SH,et al. MRI findings and spreading patterns of necrotizing external otitis: is a poor outcome predictable? Clin Radiol 2006; 61:495-504

\section{SRPSKI}

\section{TEŠKOĆE U DIJAGNOSTICI MALIGNOG OTITISA EKSTERNE}

\section{Janićijević M.}

Medicinski fakultet Priština - Katedra za Otorinolaringologiju

\section{SAŽETAK}

U radu je prikazan slučaj pacijenta starosti 70.godina dijabetičara,koji je primljen u Kliniku za ORL i MFH kao hitan slučaj zbog jake otalgije u desnom uvu,desnom mastoidnom nastavku,paralize facijalisa kao i supuracije iz desnog uva koji su trajali mesec dana pre hospitalizacije.Inicijalnom dijagnostikom na prijemu konstatovan je edem kože spoljašnjeg slušnog kanala,zbog kojeg je bilo onemogućeno vizuelizovati bubnu opnu.Vidljive su bile granulacije na podu ssh.U toku hospitalizacije pacijent je bio podvrgnut konzervativnom i hirurškom lečenju gde je i potvrđeno da se radi o Malignom Otitis Eksterni.

Ključne reči: paraliza facijalisa,supuracija,otalgija,granulacije,dijabetes melitus. 